\title{
Sanctions on digital platforms: beyond the public-private divide*
}

\author{
Enguerrand Marique \\ PhD Candidate, CRIDES, UCLouvain, Louvain-la-Neuve, Belgium \\ Yseult Marique \\ Senior Lecturer, University of Essex, Colchester, UK and Research Fellow, FÖV Speyer, Germany
}

Against a background of extensive literature examining how digital platforms are regulated through 'soft' mechanisms, this paper analyses the 'hard law' techniques, such as sanctions, which are also very much used on digital platforms to police undesirable behaviours. It illustrates the use of these sanctions, suggesting that it is possible to find three different categories of sanctions: sanctions that find their source in hard (international and domestic) law, sanctions that find their source in digital platforms' own normative production, and sanctions used in the course of disputes. Platform operators can have an intense power of norm-setting and sanctions, with a tendency to concentrate power within themselves or with unclear arrangements for dividing it across different entities. This can deeply affect individual freedoms. This paper suggests that the ways in which the power to set, decide and enforce sanctions is exercised in the digital space transform the public-private divide: the allocation of roles between sovereign public bodies and free private actors is reshaped to become 'hybrid' when it comes to enforcing rules and monitoring compliance through a wide range of sanctions on digital platforms. This paper frames the legitimacy questions arising from sanctions and suggests that the public-private divide may have to be bridged in order to locate a possible source of legitimacy. A future framework for assessing how platform operators set norms and ensure compliance through sanctions needs to start from individual users to see how best to protect their freedom when checks and balances around platforms' powers and sanctions are developed. These individual users are the ones who suffer from the economic, social and reputational consequences of sanctions in both the digital world and the physical world.

Keywords: digital platforms, regulation, sanctions, legitimacy

\section{INTRODUCTION}

The internet is the modern form of the 'new world', a place where the rules of the game are in the process of being defined. A key question is: who is setting these rules and who is in a position to enforce them; hence, who can impose sanctions on offenders? The uncertainty pertaining to answering these questions is reinforced by the transnational and international dimensions of the internet.

* We gratefully acknowledge the discussions at the 8th Annual Conference of International Law, Cambridge (20-21 March 2019); the generous comments offered by Professor Benedict Kingsbury and Thomas Streinz; and the two anonymous referees who have opened new avenues for reflection in our work. 
In 1996 John Barlow argued in favour of the withdrawal of States from this newly created space and of giving the internet space the right to self-determination. ${ }^{1}$ This approach was acknowledged by United Nations General Assembly Resolution 56/183 and the Tunis Agenda, ${ }^{2}$ which called for convening an annual multi-stakeholder meeting: the so-called 'Internet Governance Forum'. However, the Forum does not have any decision-making power and is merely a place for sharing information about cyberspace. Since then, discussions on the 'soft teeth' of the law in cyberspace have been at the forefront of legal scholarship. ${ }^{3}$ Research has so far focused on norm-setting in the digital sphere, leaving sanctions little charted. Facing this literature gap, this paper explores the 'digital legal order' through positivist lenses. It takes sanctions as indicative of the authority exercised by platform operators in the digital space.

The lack of consensus on the rules applying in the digital sphere is compounded by the fact that full digitalisation does not exist: there is no full extra-territorialisation of digital interactions. They are never completely disconnected from a physical anchor in the concrete world. However, the actual link between online activities and the physical world can be legally complex. Bad behaviours can have a partial source in the physical world when they relate to physical objects, spaces or pictures of real objects. They can also lead to actual sanctions in the physical world, for instance in the form of fines. In between, operators (ie the economic actors running the platforms) may design a whole set of rules to regulate behaviour on digital platforms (ie the technical interface between agents). Operators can act as a transmission belt for sanctioning behaviours that others have deemed illegal. They can enforce their own understanding of what acceptable behaviour online is. They can mitigate conflicts that arise between users on platforms.

This paper analyses different strategies and roles that operators have developed to police platforms. In doing so, it mainly investigates how powers are allocated between public entities and private entities. This question of power allocation has two facets. On the one hand, modern notions of sovereignty imply that public authorities are sovereign in the sense that they have the authority to set norms and to apply sanctions when these norms are infringed. Private actors have to comply with these norms, yet sanctions can only be imposed following due process so that individual freedom is not arbitrarily encroached upon. On the other hand, the principle of power separation means that the same entity should not concentrate powers, ie that one single entity should not exercise the functions of rule-making (or norm-setting) and rule implementation and enforcement (most notably through sanctions). ${ }^{4}$ This leaves open a range of possible modalities for organising the allocation of powers between public and private actors in the digital space.

1. See John Perry Barlow, 'A Declaration of the Independence of Cyberspace' (Davos, Switzerland, 8 February 1996) <https://www.eff.org/fr/cyberspace-independence> accessed 22 July 2019.

2. See the Tunis Agenda for the Information Society, accessible at <itu.int/net/wsis/docs $2 /$ tunis/off/6rev1.html> accessed 22 July 2019.

3. Luca Belli, De la Gouvernance à la Régulation de l'Internet (Berger-Levrault, BoulogneBillancourt 2016); Dimitrios Koukiadis, Reconstituting Internet Normativity: The Role of State, Private Actors, Global Online Community in the Production of Legal Norms (Hart-Nomos, Baden-Baden 2015); Chris Reed, Making Laws for Cyberspace (OUP, Oxford 2012).

4. For a critical discussion of this approach to power separation, see Bruce Ackermann, 'Good Bye, Montesquieu' in Susan Rose-Ackerman, Peter Lindseth and Blake Emerson (eds), Comparative Administrative Law (2nd edn, Edward Elgar Publishing, Cheltenham 2017) 38. 
This paper aims to analyse these modalities based on illustrations drawn mainly from the practices used on the major digital platforms (Facebook, YouTube, Airbnb, Uber, Yahoo!, etc.). It will argue that the transnational nature of digital platforms calls for international public-private cooperation to address the hybridity in enforcement regimes. This hybridity leads either to extending public-private participation in setting sanctions in the digital space or to setting up hybrid institutions to address the excesses to which sovereign platforms may be exposed. This paper will first analyse the types of sanctions imposed by platform operators (Section 2), before assessing the legitimacy of sanctions in the digital space (Section 3). It will then suggest alternative solutions (Section 4) before concluding (Section 5).

\section{SANCTIONS IMPOSED BY PLATFORMS}

Platform operators can impose sanctions in three different sets of circumstances. First, they impose sanctions upon users because the law imposes responsibility directly on them or because a judicial decision has made platform operators liable for enforcing the law (Section 2.1). Second, they impose sanctions upon users following norms that they have set (Section 2.2), and third, when they are called upon to adjudicate disputes arising from online interactions between users (Section 2.3). This leads to multiple layers of sanctions imposed by platforms (Section 2.4).

In each of these cases, a similar structure has to be in place: a norm identifies an inappropriate (or illegal) behaviour; powers are granted to an entity to monitor behaviour online or manage complaints; a procedure for this monitoring and management has to be designed; a sanction is decided upon and then enforced. What varies between the three sets of circumstances mentioned above is: (1) the role of public authorities in predefining norms, inappropriate behaviour, processes and sanctions; and (2) the correlative freedom of discretion enjoyed by platform operators in filling in the gaps in predefined norms, inappropriate behaviour, processes and sanctions. Depending on their scope of discretion, platform operators may create norms and act more or less as sovereign bodies identifying most aspects pertaining to sanctions.

\subsection{Legal grounds for platforms to enforce sanctions}

States are materially unable to enforce their national laws against the multitude of internet users. ${ }^{5}$ They have thus chosen to rely on internet intermediaries (internet access providers, internet service providers, cloud storage providers and digital platforms) to enforce their national laws in the digital world. States have made these intermediaries liable for enforcing national laws in general and national decisions against users' behaviours ${ }^{6}$ in particular. This means that internet intermediaries have the opportunity to impose sanctions (eg excluding people from a website or from certain services) at the expense of misbehaving users. ${ }^{7}$ Case law illustrates these techniques

5. Reed (n 3) 49-54.

6. Marketa Trimble, 'Extraterritorial Enforcement of National Laws in Connection with Online Commercial Activity' in John A Rothschild (ed), Research Handbook on Electronic Commerce Law (Edward Elgar Publishing, Cheltenham 2016) 261, 271-279.

7. In the UK: Cartier Int'l AG v British Sky Broadcasting [2018] UKSC 28; in the USA: Tiffany $v$ eBay (see Irene Calboli, 'Contributory Trademark Infringement on the Internet: 
and how the extra-territoriality of platforms tends to displace the boundary between the public and private spheres.

One of the first decisions on the power conferred to platforms to impose a sanction on users resulted from the Yahoo! v LICRA ${ }^{8}$ case. Yahoo! had created an auction platform mainly for the American market, which was also accessible from the French territory. On this platform, paraphernalia featuring Nazi symbols were sold. A French association against anti-Semitism, and the French Alliance of Jewish Students, introduced a complaint against Yahoo! for promoting Nazism. They requested the judge to suspend Yahoo!'s activities promoting national socialism in France and to remove listings of any Nazi memorabilia from the website. French legislation made it a criminal offence to buy or even to display certain Nazi content. Yahoo! argued it was technically impossible to prevent French users from accessing the auction website for memorabilia. However, the court found that Yahoo! deemed internet protocol (IP) localisation precise enough to use it for targeted advertising. As Yahoo! had invested much money in developing such a precise tool for advertising, the judge found that Yahoo! could not argue that the technological means for localisation were inefficient. ${ }^{9}$ Arguing otherwise would have required Yahoo! to recognise that it was basically 'throwing money out the window'. The judge thus held that Yahoo! should remove the sections and listings pertaining to anti-Semitic items from its website. As a consequence, Yahoo! barred all French users from this part of the auctioning platform.

Abundant case law features litigation pertaining to the secondary (and injunctive) liability of digital platforms for intellectual property infringements, a field where most judicial challenges related to digital platforms have been made globally. In terms of copyright, platforms have been made liable for the behaviour of another party who is primarily infringing on intellectual property rights. Platforms are found responsible because of their contributory or facilitative role in the primary infringement. ${ }^{10}$ The very nature of the platforms exacerbates copyright infringements - ie in terms of their reach or the damage they cause. As operators are made liable for copyright infringements by other users, they are incentivised to police more actively and closely the contents of activities undertaken on their platforms. For instance, the Megaupload founders were criminally convicted for the copyright infringements

Shouldn't Intermediaries Finally Know What They Need to "Know" and "Control"?' in John A Rothschild (ed), Research Handbook on Electronic Commerce Law (Edward Elgar Publishing, Cheltenham 2016) 211, 218-219).

8. Paris Trial court, Ligue Contre le Racisme et l'Antisémitisme v Yahoo!, 20 November 2000; Yahoo! Inc. v La Ligue Contre Le Racisme et l'Antisémitisme, 379 F 3d 1120 (9th Ct, 23 August 2004).

9. The experts at the time considered that 'GPS' localisation technology was not widespread enough in computers and thus favoured focusing on the IP addresses. However, now, more than $8 \%$ of the population who own a mobile phone own a smartphone (which is a higher rate than the $70 \%$ accuracy test for IP addresses, which was deemed sufficient by the French judge). See Statista, 'Penetration Rate of Smartphones Among Mobile Phone Users in France from 2014 to 2019'<https:/www.statista.com/statistics/764454/users-smartphone-phones-portable-la-france/ $>$ accessed 22 July 2019. However, experts have found that the use of geolocalisation can affect privacy more than the use of IP addresses does.

10. See eg Jaani Riordan, The Liability of Internet Intermediaries (OUP, Oxford 2016) 114-116. 
taking place on their website and the website was subsequently shut down because of under-policing. ${ }^{11}$

Within the European Union (EU), the e-commerce directive shields platforms from primary infringement liability and prohibits States from imposing a general monitoring duty for the provision of information society services. ${ }^{12}$ A distinction needs to be drawn depending on the role platforms play in facilitating illegal behaviour. In some cases, platforms will remain passive, ie they do not play an active role in the marketing of the products on offer. In these instances, the Court of Justice of the European Union (CJEU) considers that platforms can be shielded from their primary liability. However, 'active' platforms do not benefit from this potential exemption. ${ }^{13}$ In addition, the CJEU case law has extended the prohibition of the general monitoring duty so as to prevent any legislation that requires platforms to implement a technical means of systematically screening all content in order to proactively monitor intellectual property infringements. ${ }^{14}$

In other instances, platforms index content that is infringing copyright regulations. This may happen for the purpose of sharing it as widely as possible. According to the CJEU, hyperlinking to infringing content does not constitute an infringement of the intellectual property in itself, as this does not meet the criteria set by Article 3 of the directive on copyrights in the information society (the so-called 'InfoSoc directive' $)^{15}$ on communicating content to the public. ${ }^{16}$ In yet more cases, platforms have spread infringing content (films and music). In The Pirate Bay case, the CJEU held that the platform's indispensable role and its deliberate intervention meant that it was liable for the primary infringement. ${ }^{17}$

While primary infringement is infrequent for digital platforms, secondary and injunctive liability can happen in many circumstances. Article 14 of the e-commerce directive compels an operator to take down content after being notified of its illegal character, thus passing the sanction on to the user. In this case, Member States can establish procedures to govern the removal or disabling of access to information. ${ }^{18}$ Within the legal framework set by Member States, operators may have to impose sanctions to stop an illegal behaviour on their platforms. Operators act on behalf of the Member States when they so police the behaviour of users on their 'virtual' space.

For these reasons, remaining a 'passive' intermediary has been at the centre of the business structure of platforms. This has been an important legal challenge for

11. Ross Drath, 'Hotfile, Megaupload, and the Future of Copyright on the Internet: What can Cyberlockers Tell Us about DMCA Reform' (2012) 12 John Marshall Review of Intellectual Property Law 205.

12. Directive 2000/31/EC of the European Parliament and of the Council of 8 June 2000 on certain legal aspects of information society services, in particular electronic commerce, in the Internal Market ('Directive on electronic commerce'), OJ L 178, 17.7.2000, 1-16.

13. CJEU, C-236/08, Google France v Louis Vuitton, 23 March 2010 (ECLI:EU:C:2010:159); CJEU, C-324/09, L'Oréal v eBay, 12 July 2011 (ECLI:EU:C:2011:474).

14. CJEU, C-360/10, SABAM v Netlog, 16 February 2012 (ECLI:EU:C:2012:85).

15. Directive 2001/29/EC of the European Parliament and of the Council of 22 May 2001 on the harmonisation of certain aspects of copyright and related rights in the information society, OJ L 167, 22.6.2001, 10-19.

16. CJEU, C-466/12, Svensson v Retriever Sverige AB, 13 February 2014 (ECLI:EU: C:2014:76). See also CJEU, C-160/15, GS Media v Sanoma Media Netherlands BV, 8 September 2016 (ECLI:EU:C:2016:644).

17. CJEU, C-610/15, Stichting Brein v Ziggo, 14 June 2017 (ECLI:EU:C:2017:456).

18. Art 14 (3) Directive on electronic commerce (n 12). 
platforms as there is no clear boundary for distinguishing a passive platform from an active platform. However, legislation has increasingly supported (and pushed) platforms to intervene and remove infringing content (hate speech, protected content). In the past, eBay did not monitor the content on its platforms in terms of compliance with intellectual property law because doing so would result in liability if they failed to find an infringing product. However, eBay had its own internal notice-and-take-down system for copyright holders. ${ }^{19}$ In early 2018, the European Commission settled this matter when it adopted a recommendation on measures to tackle illegal content online effectively: ${ }^{20}$ proactive monitoring does not affect the 'passive' role of platforms, supporting the sanctioning power of platforms while keeping them shielded from liability. In addition, the directive on copyright in the digital single market ${ }^{21}$ sets forward the mechanism of 'notice and stay down', meaning that the copyright holder should only signal the existence of infringing content, and any further replication of this content should be removed ipso facto (ie with the best efforts) by the platform (under Article 17 of the directive). ${ }^{22}$ Within the US, the Digital Millennium Copyright Act 1998 provides a similar mechanism of primarily liability shield and notice-and-takedown procedures. ${ }^{23}$

Being passive means that platforms are only offering an electronic space where other actors can make their transactions. In this case, platforms are in the position of a laissez-faire type of body creating a collective space where users can make transactions freely, provided that they act in accordance with State regulations. In contrast to passive platforms, active platforms curate content, ie they either promote content or have 'police agents' on that electronic space ensuring that the traffic occurs according to the rulebook. Once platforms become active, they need to be extremely careful in their deeds. Any action could make them run the risk of being liable themselves in cases of mistakes with regard to claims related to freedom of expression or intellectual property. Thus, in one case, platforms act as a quasi-public power (when they police content) and, in the other case, they act as private actors (when they promote content for advertisement purposes, for instance). This illustrates the ubiquity of roles that platforms play in relation to their users in the digital space.

When platforms have knowledge of the infringing character of content put online, they become active and have a legal duty to remove it and thus to sanction their users. ${ }^{24}$ Platforms are actually a transmission belt for the enforcement of norms set by public authorities. Their contribution to this enforcement is that they make compliance with these norms more efficient and pervasive. Private actors behave as the

19. David Baron, 'Private Ordering on the Internet: The eBay Community of Traders' (2002) 4 Business and Politics 250 .

20. Commission Recommendation of 1.3.2018 on measures to effectively tackle illegal content online (C(2018) 1177 final).

21. Directive (EU) 2019/790 of the European Parliament and of the Council of 17 April 2019 on copyright and related rights in the Digital Single Market, OJ L 130, 17.5.2019, 92-125.

22. This article is controversial for the potentially chilling effect of the extensive power granted to platforms. See Will Slauter, 'Copyright and the News: The EU's Attempt to Rein in the Internet Giants May Backfire', The Conversation <https://theconversation.com/ copyright-and-the-news-the-eus-attempt-to-rein-in-the-internet-giants-may-backfire-98952> accessed 22 July 2019.

23. 17 U.S.C. $\$ 512$ (c).

24. OECD, The Role of Internet Intermediaries on Advancing Public Policy Objectives (OECD Publishing, Paris 2011) 143-149. 
'armed face' of the public authorities in the digital space, to avoid being themselves sanctioned in the physical world.

\subsection{Contractual ordering}

Besides these sanctions for breaching domestic/EU/international law, platform operators have also developed their own systems, setting the norms applicable on their platforms, and distinguishing acceptable social behaviours from problematic social behaviours on the platform. They operate this norm-setting mainly through contractual agreements. ${ }^{25}$ They set a code of behaviour for the interactions among users on the platform and for the relationships between these users and themselves, the operators. In a second step, platform operators monitor how their users respect these norms and codes. They implement and enforce the rules that they have set out in their contractual agreements. Either compliance with the code ensues or sanctions will be imposed on offenders. Depending on the problematic behaviour, the sanction may be limited (eg blocking a picture or a(n) operation/transaction) or it can be more drastic (eg blocking the user for a longer period of time or even permanently). In the physical world, these types of sanctions would often need to be clearly defined beforehand and be subject to a due process or to the possibility of external review, as a user would be restricted in her/his freedom or see some benefits resulting from her/his social belonging being taken away.

In the first place, platform operators develop their platform code, ie the lens through which the user will perceive her/his relationship with the platform, and thus the interaction options open to her/him. For instance, Amazon does not authorise contacting providers directly through the platform before a purchase. Booking.com does not provide a direct mailing system to hotels, who could then make the reservation on their side without paying Booking.com's commission/intermediation fee. This reduces the cost for users and increases the revenue for the platform. ListMinut (the Belgiumbased 'TaskRabbit') automatically filters any personal information (including email address, last name and phone number) communicated before the transaction is confirmed so that the payment has to take place through the platform, which can then get paid a brokerage commission. Allying both coding and monitoring, platform operators also ensure that users comply with community guidelines and terms and conditions, such as the interdiction of accepting any money outside of the platform. In these cases, the code shapes interactions with the platform and the way rules are enforced: a sanction can be either implicit (no way to deviate from the technical/design norm) or explicit (eg removal of content).

Second, platform operators monitor the content provided online. Each platform develops its own approach to monitoring content. For instance, Amazon can choose the kind of content it offers. In 2000, Yahoo! could have chosen to monitor the content offered on its auction platform and only allowed secondhand furniture sales, thus not becoming active in the market segment of Nazi memorabilia sales. ${ }^{26}$ It could also have included in its Terms of Services (ToS) that such pieces would not be admitted for auction. Facebook has large teams of employees reviewing pictures which users have

25. Luca Belli and Jamila Venturini, 'Private Ordering and the Rise of Terms of Service as Cyber-Regulation' (2016) 5(4) Internet Policy Review 1.

26. Marc H Greenberg, 'A Return to Lilliput: The LICRA v. Yahoo! - Case and the Regulation of Online Content in the World Market' (2003) 18 Berkeley Technology Law Journal 1191, 1194ff. 
flagged as illegal or as not complying with the community guidelines. ${ }^{27}$ If inappropriate, these employees will eventually remove them from the platform. This was for instance the case with the removal of pictures of mothers breastfeeding, which led to an outcry in many countries. ${ }^{28}$ TaskRabbit carries out checks on the backgrounds of its service providers to ensure the highest standard of quality in its service provision. ${ }^{29}$ Uber has the power to unilaterally exclude drivers whose ratings are too low.

Most of the monitoring and enforcement initiatives that platform operators can undertake have the character of 'administrative' sanctions, meaning that platforms do not have to adjudicate, ie 'pick a side' between two parties who argue in dissimilar ways. Sanctions are, rather, adopted unilaterally by platform operators in order to ensure a certain level of discipline and to regulate interactions and social behaviour on platforms. What is primarily at stake is that a norm (set by a public body or a platform) has been infringed, not the rights of another user on the platform. Questions of extra-territoriality may arise because links with specific jurisdictions can be difficult to disentangle. ${ }^{30}$ Operators, users and norms set up by specific public authorities may fall within different jurisdictions. A key question will be whether a public body can rely on private actors to extend the reach of its sanctioning power. This may be more efficient and needed in technological terms, yet it may lead to possible tensions between different jurisdictions. How do platforms navigate this uncertainty? Do they develop their own sanctioning systems as digital islands? Do they isolate themselves from the physical world thanks to their contractual regulation leading to a form of self-regulation? How can the public-private interfaces between the physical and the digital worlds be shaped? Are we witnessing a form of transnational hybrid needing its own rules of the game? Is this something international law is called on to develop, and if so, how?

\subsection{Platforms as quasi-judges}

Platforms play also an intermediary role in solving conflicts. They behave as the 'adjudicative arm' of the sovereign. This closely relates to the debate on alternative dispute resolution and in particular to arbitration in commercial and non-commercial matters. Here, we understand the extension of platforms to judicial activities as an increase of the 'private' sphere in which users are immersed as soon as they join a platform. Beyond arbitration, some platforms impose a duty to mitigate conflict through them first, and only later become the recipient of a formal claim against other users. ${ }^{31}$

27. See eg the documentary 'The Cleaners' (in German 'Im Schatten der Netzwelt') by Hans Block and Moritz Riesewieck (2018).

28. See eg Glenda Cooper, 'Why "Lactivists" are Milking Facebook's Breastfeeding Ban', The Telegraph (London, 10 February 2012) <https://www.telegraph.co.uk/technology/face book/9072201/Why-lactivists-are-milking-Facebooks-breastfeeding-ban.html $>$ accessed 22 July 2019.

29. TaskRabbit, 'How It Works' <https://www.taskrabbit.com/how-it-works > accessed 21 September 2019 ('Taskers undergo an extensive screening process before they can join our community. Every Tasker must pass an identity check and is screened for criminal offenses. This background check collects information from national, local, and sex offender databases'). 30. For issues with transnational sanctioning in the physical world, see Oswald Jansen, 'Transnational Sanctioning in EU Law' < https://unimaas.academia.edu/OswaldJansen> accessed 22 July 2019.

31. Jorge Morais Carvalho and Joana Campos Carvalho, 'Online Dispute Resolution Platform: Making European Contract Law More Effective' in Alberto de Franceschi (ed), European Contract Law and the Digital Single Market (Intersentia, Cambridge 2016) 245; Rodrigo 
In many State judiciary systems, basic principles regulate adjudication, especially the publicity of the applicable norms, processes and sanctions, the impartiality of the judge and the right to be heard. The main objective is to foster trust in the system and legal certainty, ending conflicts and ensuring life can go on peacefully. Platform operators have developed their roles as 'quasi-judges' diversely and creatively. To some extent, they attempt to recreate some of the conditions fostering similar trust on their platforms. This paper reviews some of these systems to ponder whether platforms acting as quasi-judges act as public bodies, and hence develop a specific blend of 'publicness' in their private ordering.

A first illustration can be taken from eBay. eBay's customer support was involved in resolving disputes amongst customers early on. After partnering with the University of Massachusetts Amherst to externalise mediation services over claims on eBay's rating system in 1999, eBay realised that many claims needed to have in-house support. In 2003, eBay made a 'smart move' and developed an in-house online dispute resolution centre. ${ }^{32}$ Due to the large number of cases, most of the decision-making needed to be automated. ${ }^{33}$ This automation was made possible because every exchange between the parties (except the delivery of goods) could be traced back to the platform. In addition to this procedure, eBay decided to design solutions for the two most common issues arising among users: item-related and unpaid item disputes. It decided to offer solutions made by the parties themselves (amicably and consensually) before involving more formal mediation and even arbitration by eBay and PayPal, which provided payment solutions on the eBay platform. By creating a filter and delaying the moment when a human being intervenes, eBay and PayPal expected to deal with a lower number of situations when intervention would be necessary. Three procedures were specifically set up for unpaid items and item-related disputes but also with regard to extortion in terms of rating and feedback-reputation, especially for high-value transactions happening at a slow pace (eg motor vehicle sales). However, when having recourse to these procedures, the rule of precedent does not apply. Rather, eBay preferred its dispute resolution team to base its decisions on a 'principle-based' resolution, established ahead of the issue. There is thus a form of top-down (rather than bottom-up) approach to decisions. This tends to mirror the requirement that sanctions have to be based on a legal text identifying behaviour and sanctions, as in classic criminal or administrative law. ${ }^{34}$

In addition, for some dispute resolution processes, especially with regard to feedback-related disputes, the resolution is outsourced to reduce the bias that users can believe the platform has. Yet the whole procedure goes through the platform itself, which provides the interface and the structure for exchanges pertaining to the issue. Hence the outsourced partner's sole role is to provide a man-made

Momberg, 'Standard Terms and Transparency in Online Contracts' in Alberto de Franceschi (ed), European Contract Law and the Digital Single Market (Intersentia, Cambridge 2016) 189; Lilian Edwards and Caroline Wilson, 'Redress and Alternative Dispute Resolution in EU Cross-Border E-Commerce Transactions' (2007) 21(3) International Review of Law, Computers \& Technology 315, 323, 326. See also: Pablo Cortés, 'Online Dispute Resolution Services: A Selected Number of Case Studies' (2014) 20(6) Computer and Telecommunications Law Review 172.

32. Colin Rule, 'Designing a Global Online Dispute Resolution System: Lessons Learned from eBay' (2017) 13 University of St. Thomas Law Journal 354, 354-355.

33 . Ibid 356.

34. For a discussion of these matters, see Agne Andrijauskaite, 'Exploring the Penumbra of Punishment under the ECHR' (2020) New Journal of European Criminal Law (forthcoming). Kindly provided by the author. 
decision. ${ }^{35}$ The underlying idea is that this system ensures the independence of dispute resolution and reduces the liability risks for eBay. This also means that the private platform operator delegates its quasi-judicial role to an external private party. This creates an organic separation between the norm-setter and the adjudicator. This also calls into question the financial and principled independence of this adjudicator if the terms of the delegation are not made widely public.

EBay's experience has paved the way for dispute resolution policies on more recent platforms. However, dispute resolution centres on other platforms do not seem as bound by principles, as is the case with eBay. Rather, witnesses have reported the huge discretionary power that platform operators enjoy. For instance, Airbnb Customer Service can choose without motivation whether and how much to refund a guest or a host. ${ }^{36}$ Initially, Airbnb was reluctant to assume any role in disputes involving users and relied heavily upon the reputation system. ${ }^{37}$ However, it soon realised that it should work on prevention by monitoring bad guests, and by better matching users. Different issues may arise with Airbnb's contracts: problems with damage caused in accommodation, cancellation issues and fraud. Airbnb also deals with non-contractual issues, such as conflicts with neighbours.

From a contractual perspective, Airbnb's terms and conditions offer first a 'host guarantee', which is not insurance per se and which requires hosts to clearly instruct guests about the expected use of accommodation, the need to compensate for any damage in the accommodation, and the need for evidence of expenses incurred to cover the damage. ${ }^{38}$ This approach has led to much criticism, as fulfilling these conditions is usually hard ${ }^{39}$ and the scope of the protection is unclear. ${ }^{40}$ The way in which Airbnb deals with damage claims seems overall unfair for all (including guests). ${ }^{41}$ Second, Airbnb's terms and conditions provide last-minute cancellation policies, which can be unclear. Some users have had to find alternative options at the last moment, which is usually expensive without any support from Airbnb. Airbnb refuses to refund users for the price difference but accepts, in certain cases, covering it, eg when it is threatened with legal action ${ }^{42}$ or when publicised in

35. Rule (n 32) 364.

36. See eg Rupert Jones, 'Airbnb Wrecks Travellers' Holiday Plans as Battle with Cities Intensifies', The Guardian (London, 16 June 2018) <https://www.theguardian.com/technol ogy/2018/jun/16/airbnb-booking-cancelled-last-minute-holiday-wrecked $>$ accessed 22 July 2019.

37. Ethan Katsh and Orna Rabinovich-Einy, 'Technology and Dispute Systems Design: Lessons from the "Sharing Economy" (2015) 21 Dispute Resolution Magazine 11.

38. Airbnb, 'Assurance Hôte' <https://www.airbnb.com/host-protection-insurance> (FR) accessed 22 July 2019. See also Ethan Katsh and Orna Rabinovich-Einy, Digital Justice: Technolology and the Internet of Disputes (OUP, New York 2017) 71-75.

39. Anna Tims, 'Why Does Airbnb's Guarantee Make it so Difficult to Claim?', The Guardian (London, 3 October 2018) <https://www.theguardian.com/money/2018/oct/03/airbnb-damageredress-guarantee> accessed 22 July 2019.

40. Ron Lieber, 'A Liability Risk for Airbnb Hosts', The New York Times (New York City, 5 December 2014) <https://www.nytimes.com/2014/12/06/your-money/airbnb-offers-home owner-liability-coverage-but-hosts-still-have-risks.html> accessed 22 July 2019.

41. Patrick Collinson, 'Why Did Airbnb Charge Me £1,500 for a Shattered Glass Door?', The Guardian (London, 28 August 2018) <https://www.theguardian.com/money/2018/aug/28/ airbnb-damage-shower-property-bill> accessed 22 July 2019.

42. Patrick Collinson, 'What Happens When Airbnb Goes Wrong?', The Guardian (London, 4 August 2018) <https://www.theguardian.com/technology/2018/aug/04/what-happens-whenairbnb-goes-wrong > accessed 22 July 2019. 
the media. ${ }^{43}$ Third, Airbnb's policy addresses cases of fraud. Under certain conditions, Airbnb agrees to refund users scammed after a false listing has been advertised on the website $^{44}$ and not been removed. Questions arise about the scope of this refund, especially when Airbnb knows that a listing misleads or scams users without reacting. However, the burden of proof is heavy on the users. ${ }^{45}$

If eBay's and Airbnb's powers to develop a private legal order are undeniable under contractual and economic freedom, what is rare is Airbnb's potential to extend its policing to claims from non-members outside any statutory duty. Indeed, Airbnb's role extends beyond contractual claims. The management of externalities is usually a feature of public entities. For instance, Airbnb agrees to mediate conflicts arising with neighbours who suffer from property rental. It has developed a tool enabling nonAirbnb users to file an 'extracontractual' (tortuous) claim against guests. ${ }^{46}$ This tool enables Airbnb to sanction guests for tarnishing Airbnb's reputation when guests cause inconvenience to neighbours, for instance by making noise or being dirty. Indeed, Airbnb tries to develop a reputation for providing 'good residents' rather than 'troublemakers' for idle rooms. Similarly, Airbnb has removed accounts of users who engage in criminal activities (eg illegal short lets ${ }^{47}$ or sexual assaults by guests). ${ }^{48}$ This can be seen as a clear sanction, akin to the removal of an illegal poster put up on a street. In the physical world, the poster-hanger could ask for this removal to be reviewed as it may encroach on her/his own individual rights if s/he has not been

43. Rebecca Smithers, 'Airbnb Cancelled Our Booking ... an Hour Before We Arrived', The Guardian (London, 30 April 2016) <https://www.theguardian.com/money/2016/apr/30/airbnbcancelled-booking-hour-before-arrived $>$ accessed 22 July 2019; Miles Bringmall, 'Airbnb Not Very Accommodating When My Rental was Cancelled', The Guardian (London, 19 September 2015) <https://www.theguardian.com/money/2015/sep/19/airbnb-not-accommo dating-rental-cancelled $>$ accessed 22 July 2019; Rebecca Smithers, 'Airbnb's Not-SoSuperhost's Last-Minute Cancellation Cost Thousands', The Guardian (London, 7 November 2017) <https://www.theguardian.com/money/2017/nov/07/airbnb-last-minute-cancellation-costthousands> accessed 22 July 2019. Contra: Anna Tims, 'I've Been Ripped Off - Now HSBC is Making it Hard For Me to Claim', The Guardian (London, 31 March 2015) <https://www.the guardian.com/money/2015/mar/31/ripped-off-hsbc-hard-to-claim> accessed 22 July 2019.

44. Anna Tims, 'When is Airbnb Not Airbnb? When it Suddenly Turns into a Scam Email', The Guardian (London, 13 May 2015) <https://www.theguardian.com/money/2015/may/13/ when-is-airbnb-not-airbnb-when-it-suddenly-turns-into-a-scam-email > accessed 22 July 2019; Rebecca Smithers, 'Was Conned by a Fraudster Pretending to be an Airbnb Host', The Guardian (London, 8 May 2017) <https://www.theguardian.com/money/2017/may/08/connedby-fraudster-airbnb-host> accessed 22 July 2019.

45. Katsh and Rabinovich-Einy (n 38) 70-71.

46. Lara Williams, 'When Airbnb Rentals Turn into Nuisance Neighbours', The Guardian (London, 18 September 2016) <https:/www.theguardian.com/technology/2016/sep/17/airbnbnuisance-neighbours-tribunal-ruling $>$ accessed 22 July 2019.

47. Rebecca Smithers, 'We Arrived at Our Airbnb Booking on Singapore Only to Find it was Illegal', The Guardian (London, 2 October 2016) <https://www.theguardian.com/money/2016/ oct/02/airbnb-illegal-singapore-building-short-lets > accessed 22 July 2019; Miles Brignall, 'Airbnb is Taking Bookings that Cannot be Fulfilled', The Guardian (London, 6 June 2016) $<$ https://www.theguardian.com/money/2016/jun/06/airbnb-bookings-berlin-law-rent-wholeapartment $>$ accessed 22 July 2019.

48. Ben Quinn, 'Man Who Let Out Home on Airbnb for New Year Suffers £12,000 Damage', The Guardian (London, 9 January 2016) <https://www.theguardian.com/technology/2016/jan/ 09/london-man-who-rented-home-out-for-new-year-airbnb-left-with-12000-damage $>$ accessed 22 July 2019. 
given the opportunity to explain herself/himself. Yet, in the physical world, practical issues with the identification of the poster-hanger would often make this a moot point.

Finally, Airbnb has also faced problems with dealing with user discrimination when attempting to build trust amongst users by increasing the information available to hosts and guests. Rather than excluding any liability of its own, Airbnb has accepted that it should ex officio promote inclusion and develop a non-discrimination policy. ${ }^{49}$ Users can complain on this basis, leading to discriminatory listings being removed ${ }^{50}$ Here, the role of the platform operator falls between an adjudicative measure taken to end a conflict arising between users on the platform on the one hand, and a unilateral measure taken to police social behaviour on the platform on the other hand. This may, however, result in platform operators engaging in a form of censorship.

\subsection{Layers of sanctions}

The second wave of digital platforms ('Web 2.0') eased access by laymen to the web and increased the opportunity to exchange information between users and economic operators. The platform structure of the Web 2.0 has quickly created heavily unbalanced market power, with the concentration of data and revenue streams in the hands of the few. In order to limit access to information available online, States have banned the use of social media at crisis times by compelling internet access providers who are anchored in the State's territoriality to cut access to those services. ${ }^{51}$ In doing so, the sanctions imposed by States on platforms percolate to the user level, as they cannot access platform services anymore.

A multiplicity of actors has contributed to the emergence and shaping of the internet, creating their own private legal orders. To sustain their power, platform operators have assimilated sanctions from States' legal orders while adding a layer of their own making. This double coating has blurred the lines between public and private enforcement mechanisms. What, then, is the legitimacy of these developments?

\section{LEGITIMACY OF PLATFORMS' DECISION-MAKING}

Ensuring compliance, sanctioning misbehaviours and adjudicating disputes require that rules are clearly established beforehand (Section 3.1), that sanctions are accepted

49. Airbnb, 'Nondiscrimination Policy' < https://www.airbnb.com/terms/nondiscrimination policy $>$ (FR) accessed 22 July 2019. See also David Hoffman, 'Relational Contracts of Adhesion' (2018) 85 University Chicago Law Review 1437.

50. Sam Levin, 'Airbnb Adopts New Rules in Effort to Fight Racial Discrimination by Hosts', The Guardian (London, 8 September 2016) <https://www.theguardian.com/technology/2016/ sep/08/airbnb-discrimination-policy-changes-racial-discrimination> accessed 26 July 2019.

51. See, eg, bans in Brazil: Natalia Scalzaretto and Caio Saad, 'Facebook CEO Urges Brazilians to Decry WhatsApp block', Reuters (3 May 2016) <https://www.reuters.com/arti cle/us-facebook-brazil-whatsapp-unblock/facebook-ceo-urges-brazilians-to-decry-whatsappblock-idUSKCNOXU1YY> accessed 22 July 2019; in Iran: Sheera Frenkel, 'Iranian Authorities Block Access to Social Media Tools', The New York Times (New York City, 2 January 2018) $<$ https://www.nytimes.com/2018/01/02/technology/iran-protests-social-media.html> accessed 22 July 2019; and in Egypt: Charles Arthur, 'Egypt Blocks Social Media Websites in Attempted Clampdown on Unrest', The Guardian (London, 26 January 2011) <https://www.the guardian.com/world/2011/jan/26/egypt-blocks-social-media-websites> accessed 22 July 2019. 
as legitimate in democratic societies based on the rule of law (Section 3.2) and that some kind of review exists in order to quash sanctions (Section 3.3).

\subsection{Rule-making framing sanctions}

The principle of sanctions needs to be established in some way, either because States have set them up (Section 3.1.1) or because States have based them on the diligence of platform operators (Section 3.1.2). The legitimacy of sanctions is assessed differently depending on their sources.

\subsubsection{States}

In terms of public bodies' rule-making, legitimacy issues can be of two kinds. On the one hand, States can direct platforms to adopt some behaviours, and sanction them for non-compliance. In this case, legitimacy questions are similar to legitimacy questions regarding any legal rules, as in Hart's rule of recognition ${ }^{52}$ or Ost's tridimensional rule of validity. ${ }^{53}$ Was the correct legislative procedure followed? Does the rule reflect the values shared among the citizens of that State? These issues are common to any legal rules, yet the need to understand the technological structures and issues arising from online platforms means that specific expertise needs to be brought in within this rule-making process. ${ }^{54}$ Furthermore, this question also concerns the issue of whether the State adopting a given rule (and the principles for its sanction) is perceived by citizens/consumers to have the authority (and understanding) needed in the given situation. $^{55}$

On the other hand, co-regulation between public and private entities has raised several (limited) issues in terms of legitimacy. To the extent that States retain some form of control over rule-making, their scrutiny legitimises the rule-making procedure. ${ }^{56}$ However, difficulties arise as soon as one tries to find the origin of a given rule: does it come from a regulatory power delegated by a legislative act or is the act in the realm of any free exercise of power by any economic actor? Such a situation becomes self-regulatory in nature and does not benefit from the same legitimacy grounds as acts originating from a State source. ${ }^{57}$

Indeed, purely self-regulatory mechanisms do not need to be as inclusive as a State's rules as third parties do not need to receive the same amount of consideration. However, the risk is that the definition of stakeholders in co-regulation is too narrow or overrepresents some sectorial interests. ${ }^{58}$ Legitimacy also depends on whether rules are approved ex ante or ex post. If rules are approved by the State ex ante this covers

52. HLA Hart, The Concept of Law (2nd edn, Clarendon Press, Oxford 1994) 100-110.

53. François Ost and Michel Van de Kerchove, De la Pyramide au Réseau: Pour une Théorie Dialectique du Droit (FUSL, Brussels 2010).

54. For a discussion of expertise and formal rationality in rule-making at times of globalisation, see David Roth-Isigkeit, The Plurality Trilemma: A Geometry of Global Legal Thought (Palgrave, Basingstoke 2018) 79-127.

55. Reed (n 3) 18-20.

56. Koukiadis (n 3) 72.

57. Ibid 78.

58. See eg Michèle Finck, 'Digital Co-Regulation: Designing a Supranational Legal Framework for the Platform Economy' (2018) 43 European Law Review 47. See also CFI, T-135/96, UEAPME v Council, 17 June 1998 (ECLI:EU:T:1998:128). 
any legitimacy claims for representation. Yet, if confirmation is ex post, this creates room for (lengthy) discussions. ${ }^{59}$

\subsubsection{Contracts}

Contractual terms may be a legitimate means of deciding upon new rules between two parties, and of policing behaviours requiring sanctions. Indeed, the theory held by proponents of regulation by perfectly competitive markets ${ }^{60}$ goes as follows: parties benefit from the freedom to contract and to choose their contractual terms. This is deemed to result in a fair agreement. However, in the absence of genuine contractual negotiations (eg in the case of adhesion contracts), a source of legitimacy other than contractual choice needs to be established. This alternative source can be found in market competition. A perfectly competitive market implies, then, that sellers have reputation concerns if they disrespect users and that buyers have lower reputation concerns than sellers. When sellers or users misbehave, the market/community creates a sanction by diminishing/tarnishing reputation, which decreases opportunities for interactions and/ or increases opportunity costs.

In practice, however, electronic contracts are of an adhesive nature rather than a negotiated one. Digital platforms do not work according to these assumptions about competitive markets: platforms are not perfectly competitive but are rather an oligopoly (with only a handful of operators acting on the supply side). In turn, platform operators do not have reputation concerns but users have very high reputation concerns because of the rating systems. Therefore, users' participation in the market cannot lead to legitimising the applicable contractual terms and the rules that these terms cause to arise.

Platform operators organise individuals' lives and impose upon them terms which are neither negotiated nor to which individuals are party ${ }^{61}$ Users often do not even feel compelled by the content of the rules or they refuse to be bound by them despite their efforts to have them applied horizontally amongst users. ${ }^{62}$ These differences explain why consenting to online 'clickwrap agreements' (ie digital shrink-wrap contracts) is subject to extensive debates. ${ }^{63}$ One can distinguish situations between different types of rules agreed in the digital space, especially community rules, ToS and privacy policies - which can all set rules whose infringement by users may lead to the platform eventually imposing sanctions on these users.

First, ToS and privacy policies contractually organise the relationship between a platform operator and users without regard to third parties. These terms, as already stated, raise issues in terms of legitimacy because of their unilateral character. Studies

59. Christopher Marsden, Internet Co-Regulation: European Law, Regulatory Governance and Legitimacy in Cyberspace (CUP, Cambridge 2011) 54.

60. Lucian Bebchuck and Richard Posner, 'One-Sided Contracts in Competitive Consumer Markets' (2006) 104 Michigan Law Review 827.

61. Luca Belli and Primavera De Filippi, 'Law of the Cloud v Law of the Land: Challenges and Opportunities for Innovation' (2012) 3(2) European Journal of Law and Technology 1, 1ff. 62. In Gentry v eBay, Inc., 99 Cal. App. 4th 819 (2002), eBay attempted to force its users to abide with certification measures (for collectible items) but tried to avoid being compelled to undertake this certification enforcement.

63. In the US, Heather Daiza, 'Wrap Contracts: How They can Work Better for Businesses and Consumers' (2018) 54 California Western Law Review 203. In Europe, Momberg (n 31). 
show that these contracts are barely read by users, ${ }^{64}$ and when they are, their technicality ${ }^{65}$ or length ${ }^{66}$ make them difficult to comprehend. Part of the issue is that they are not meant to be read, as indicated by their strict fine print format, whereas the rest of the online environment is full of images and colours. ${ }^{67}$

Second, community rules are sometimes referred to as a 'social contract' that users agree to comply with when they interact on a platform, ${ }^{68}$ although this contract is not negotiated by users but established by platforms. These rules usually merely bind users with other users, not the platform operator. In a true Social Contract à la Rousseau, users should be the ones coming up with the terms of community rules and should have participatory interests in the modification of these rules. ${ }^{69}$ They would freely accept some restrictions to their freedom in return for social peace. Community rules would be agreed upon to the benefit of the general interest only. In practice, the interest represented in digital platforms' community rules is often the one pursued by the drafting party (the platform operator), rather than that of the whole community of users. In certain circumstances, a platform can identify its own interest as being the same as that of the platform users, eg good reputation hygiene for users will spill over onto the platform's reputation. ${ }^{70}$ In this case community guidelines can benefit from the legitimacy of a social contract. However, these circumstances are more the exception than the rule: the social contract in the context of digital platform governance is only of limited relevance in identifying the legitimacy of rules set out on platforms and the subsequent sanctions imposed in cases of infringement. ${ }^{71}$

Once the legitimacy of the social contract is addressed, we can turn to the conditions for legitimising the power entrusted to an entity when it exercises discipline. This entity (either a sovereign or some superior authority-in practice a platform operator or an entity designated by it) is required to build trust through technical features (eg payment systems, ratings) but also thanks to discipline through penalties to ensure compliance with the social contract. The legitimacy in using this disciplining power pertains to the trust-building process on platforms. Mere neutrality of platform operators is not enough, as it is difficult to know what this neutrality entails.

64. Jonathan Obar and Anne Oeldorf-Hirsch, 'The Biggest Lie on the Internet: Ignoring the Privacy Policies and Terms of Service Policies of Social Networking Services' (2018) Information, Communication \& Society 1.

65. Yannis Bakos, Florencia Marotta-Wurgler and David R Trossen, 'Does Anyone Read the Fine Print? Consumer Attention to Standard Form Contracts' (2014) 43 Journal of Legal Studies 1.

66. Aleecia McDonald and Lorrie Cranor, 'The Cost of Reading Privacy Policies' (2008) 4 Journal of Law and Policy for the Information Society 543.

67. See Nancy S Kim, 'The Duty to Draft Reasonably and Online Contracts' in Keith Rowley, Larry A DiMatteo, Qi Zhou et al (eds), Commercial Contract Law: Transatlantic Perspectives (CUP, Cambridge 2013) 180.

68. Przemyslaw J Palka, 'Terms of Service are not Contracts: Beyond Contract Law in the Regulation of Online Platforms' in Stefan Grundmann (ed), European Contract Law in the Digital Age, vol 3 (European Contract Law and Theory Intersentia, Cambridge/Antwerp/ Portland 2018) 136.

69. Rolf Weber, Shaping Internet Governance: Regulatory Challenges (Springer, Zurich 2010) 80-83.

70. David P Baron, 'Private Ordering on the Internet: The eBay Community of Traders' (2002) 4 Business and Politics 245.

71. Joni Salmien, Nicolas Gach and Valtteri Kaartemo, 'Platform as a Social Contract: An Analytical Framework for Studying Social Dynamics in Online Platforms' in Anssi Smedlund, Arto Lindblom and Lasse Mitronen (eds), Collaborative Value Co-Creation in the Platform Economy (Springer, Singapore 2018) 43. 
For instance, should a platform foster freedom of information in the name of 'nonintervention' or should it seek to protect users from disinformation $?^{72}$ Users should thus experience concretely that a platform is advancing/enforcing the social contract to the benefit of the community of users. ${ }^{73}$ As a consequence, users will also make the rules theirs. Otherwise users seek alternative rules which they find more legitimate. They will exit a platform and conduct their interactions elsewhere in the digital space ${ }^{74}$ or they will challenge the rules judicially in the physical world. Here a lack of legitimacy in rule-setting may lead to users sanctioning platforms for failing to foster a minimal amount of trust in them. A classic example of this type of user reaction is the legal challenges by Uber drivers who find the rules (and the sanctions deriving from them) to be illegitimate. The drivers thus seek to characterise their relationship as a labour law contract with the platform, shifting away from being independent contractors. Indeed, Uber wanted them to work as independent contractors in each contract concluded with riders on each ride, as derived from the 'framework contract' initially concluded by drivers with the platform. ${ }^{75}$ In contrast, in competitive markets (at least) some actors try to develop more legitimacy to distinguish themselves and attract more users to their platforms.

Alternatively, in Hoffman's 'relational contract of adhesion' ${ }^{76}$ some sharing economy platforms reduce the number of liability waivers for platforms and could actually be considered as creating legitimacy for sanction-making within adhesion contracts. Indeed, a platform operator can also be found more liable and develop alternative strategies to become more legitimate: restricting liability waivers compels customer services to establish a long-lasting relationship with their users through brand alignment rather than through an adhesive contract. ${ }^{77}$

However, the unilateral character of ToS does not always have to be. For instance, Facebook launched an inaugural vote in 2009 after a backlash against proposed changes in its ToS. For the results of the vote to be valid, $30 \%$ of the existing community needed to vote. In practice, auditors found that almost $80 \%$ of the community expressed their voice. ${ }^{78}$ Any further amendment would be submitted to the same rule. However, this fostered a very high turnout of comments with limited added value. From 2012, Facebook changed its governance approach and only allowed for comments on their amendment proposals. This move was meant to increase the quality of feedback. This should in turn have had a beneficial effect on the sanctions included in these ToS by providing sanctions which are more appropriate and better targeted in cases of misbehaviour.

Another illustration of a social-contract-like situation is given by eBay. Indeed, eBay merely enforces the terms of use after users try to sell fraudulent objects by

72. Ibid 61 .

73. Ibid 52.

74. Per analogy to the ideas developed in Albert Hirschman, Exit, Voice, and Loyalty (Harvard University Press, Cambridge MA 1970).

75. Uber BV c Aslam [2018] EWCA Civ 2748. See also French Court of Cassation (the highest court of the judicial order), Take Eat Easy, case nr 17-20.079, 28 November 2018.

76. According to Hoffman ( $\mathrm{n} 49$ ), the 'relational contract of adhesion' is an adhesion contract which aims to establish long-term trust between parties and thus requires getting rid of abusive terms in order to let trust grow.

77. Hoffman (n 49) 1452.

78. Lee A Bygrave, Internet Governance by Contract (OUP, Oxford 2015) 98; Facebook, 'Facebook Site Governance' <https://www.facebook.com/fbsitegovernance> accessed 22 July 2019. 
referring these users to the appropriate law enforcement agencies (despite eBay not being defrauded itself). It leaves enforcement of the community's principles to the community itself through the reputation mechanism. Where the community and the terms of service sides merge is when eBay suspends users with a too-bad rating (as a consequence of not abiding with eBay's contractual commitments for a given set of transactions). In addition, eBay keeps track of users because users need to log in with their credit cards to verify their identity and thus excludes users who try to participate again with a different username (but with another credit card number for instance, although the number of credit cards that any given individual can have is rather limited and hence does not allow for a large number of accounts to be created) ${ }^{79}$

Finally, an important aspect of assessing the legitimacy of the contractual process of rule-making is the clarity of the contractual scheme regulating transactions and behaviours on a platform. Many different contracts with several purposes often regulate these transactions and behaviours. A user will be bound with the same platform operator with five, ten or sometimes even more contracts at the same time for a single transaction. ${ }^{80}$ For instance, users are bound on Uber with no fewer than 16 different legal documents. In Brussels the contractual structure is even more complicated, so as to comply with regulatory requirements. ${ }^{81}$

\subsection{Legitimacy of sanctioning in se}

The very fact of imposing sanctions in a given instance can be primarily grounded in some form of State decisions (Section 3.2.1) or in platform operators' discretion (Section 3.2.2). Different legitimacy issues arise again, as is the case with general frame-setting sanctions, as discussed in Section 3.1 above.

\subsubsection{State decisions}

When platforms apply a sanction to a user on grounds found in national (or European/ international) law, two situations can arise. First, as already mentioned, platforms merely comply with a decision made by judicial bodies or government/executive agencies. Two categories of decisions should be distinguished. On the one hand, a decision may emanate from a country in which the party that needs to comply is a resident, a national or has other close ties. In this case, the legitimacy of the sanction can be assessed through rule of law criteria, such as whether the government is accountable, whether the sanctioning procedure follows a fair process, and whether the punished user has had an opportunity to be heard, appealed or get some judicial review. On the other hand, a decision may emanate from a country with which the party that needs to comply has limited ties. For instance, judges may require a platform operator to abide with (foreign) rules, which raises legitimacy issues regarding the extraterritorial application of a law. Two cases illustrate this point. In the Yahoo! case, ${ }^{82}$

79. Baron (n 70) 245-274.

80. Guido Noto La Diega, 'Uber Law and Awareness by Design: An Empirical Study on Online Platforms and Dehumanised Negotiations' (2015) 2015(2) European Journal of Consumer Law - Revue Européenne de Droit de la Consommation 383, 403-406.

81. Brussels Business Tribunal (Belgium, in French), TRB v Uber, 16.1.2019, unpublished (on file with the authors).

82. See $n 8$. 
the question was raised before American judges as to whether the French judgment was to be recognised in the United States. ${ }^{83}$ In a more recent case, Microsoft faced legitimacy issues when abiding with an executive order in the US (a subpoena) to produce data hosted on a server in Ireland. European data protection rules forbade Microsoft from providing these pieces of information to foreign authorities. These types of clashes between rules raise legitimacy issues at their core. ${ }^{84}$ They also illustrate the difficult interactions between the scopes of different public norms once private actors have to comply with them across several jurisdictions. This leads to questions about finding principles, techniques or concepts that reach beyond the traditional public-private boundaries.

Second, platforms can also enjoy discretionary power in terms of rule-making ${ }^{85}$ or in order to proceed to the legal characterisation of some incidents. Issues then become even more complex. Debates on the legitimacy of delegating power to private actors are not novel. Black ${ }^{86}$ and $\mathrm{Ofcom}^{87}$ have, for instance, long discussed the forms under which delegation can take place. This forms a kind of 'continuum' going from strict mandated delegation to discretionary self-regulation without State involvement. ${ }^{88}$ However, many of the successful examples of co-regulation cited in the literature rely on delegating decision-making to bodies (ie entities composed of a series of private actors with at least some form of competitive interests between them, thus potentially allowing for at least minimal external oversight or constraints over unilateral power). ${ }^{89}$ Regulation delegated directly to social networks or online gaming platforms seems scarce and an underexplored path. ${ }^{90}$ Delegation of standards setting and enforcement to private consortia can be problematic. ${ }^{91}$ Delegation to digital platforms can be even more problematic. For instance, Uber enjoys discretion in establishing whether drivers are deemed to be 'fit to drive' in London. This leads to risks of creating discrepancies and discrimination amongst market actors. ${ }^{92}$ Indeed, the criterion taken into consideration by a platform in such a situation is more likely to be one of efficiency than of skills, expertise or experience. ${ }^{93}$

A sanction can thus legitimately be questioned: how fair was the sanction? What is algorithmically decided? Was it a man-made decision? What are the actual grounds for this sanction? Has it been checked for factual accuracy in any way? To answer these questions, it is necessary to turn to administrative law (especially transparency and the

83. Reed (n 3) 30-33.

84. Andrew Woods, 'Against Data Exceptionalism' (2016) 68 Stanford Law Review 729.

85. See above discussion under Section 3.1.

86. Julia Black, 'Constitutionalising Self-Regulation' (1996) 59 MLR 24.

87. Ofcom, 'Online Protection: A Survey of Consumer, Industry and Regulatory Mechanisms and Systems' (21 June 2006) <https://www.ofcom.org.uk/research-and-data/internet-and-ondemand-research/internet-use-and-attitudes/online-protection> accessed 22 July 2019, 12.

88. Marsden (n 59) 51-62.

89. Ibid $38-43$.

90. Ibid 38-39.

91. For a discussion of some problems, see Mariolina Eliantonio, 'Private Actors, Public Authorities and the Relevance of Public Law in the Process of European Standardization' (2018) 24 European Public Law 473.

92. Enguerrand Marique and Yseult Marique, 'Uber in London: A Battle Between Public and Private Regulation' in David Renders and Rozen Noguellou (eds), Uber and Taxis: Comparative Law Studies (Bruylant, Brussels 2018) 163-200, 175 and 177-178.

93. Belli and Venturini (n 25) 5. 
duty to give reasons) so as to ensure that a decision is (1) legitimate and (2) subject to judicial review. ${ }^{94}$

\subsubsection{Platform operators' discretion}

Last but not least, sanctions can be imposed by platforms for policies which are fully self-regulated and do not implement any statutory law. Many activities in the digital space are left for self-governance by private actors. Moreover, many design mechanisms compel users' behaviours and do not leave any leeway to misbehave. Hence, no sanction is really set up: users' individual freedom is limited to opt-in/opt-out. However, one may want to be mindful that practices which would seem to fall within the reach of self-regulation may not in fact have clear hard law underpinning them. For instance, the Internet Corporation for Assigned Names and Numbers (ICANN) is often thought of as constituting a wholly private entity having completely autonomous selfregulation with regards to allocation of domain names. Yet a closer look at the activities of the ICANN shows that it is under the supervisory authority of governments (despite some oversight changes in 2016). Additionally, regulation of domain names has been largely left to States. For instance, the USA has voted the Anticybersquatting Consumer Protection Act, ${ }^{95}$ while many other countries also have their own equivalent rules. ${ }^{96}$ Despite the absence of statutory rules in the United Kingdom, the latter resorts to traditional tort law before the traditional court system when someone cybersquats (ie registers unduly an internet domain name protected by a trademark held by a third party) and requires that the domain name be handed over to the legitimate owner. ${ }^{97}$ In these cases, the situation is then similar to the one analysed in the previous subsection.

This section is more devoted to situations where there is no direct or indirect legislation or delegation of enforcement to platforms. This can be the case when ToS solely apply. Two examples of such rules illustrate legitimacy issues arising from these situations. First, the prohibition, by Facebook, of publishing artistic nudes (eg a naked Venus) in France, ${ }^{98}$ Switzerland ${ }^{99}$ or Belgium ${ }^{100}$ has been understood as a limitation on freedom of expression, while some violent and graphic content is

94. This argument is also supported by A G Szpunar's opinion in the CJEU case Airbnb Ireland, where he discusses the 'power of administrative control' that some platforms have (C-390/18, 30 April 2019, [75]-[76]) (ECLI:EU:C:2019:336).

95. 15 USC, $\$ 1125(\mathrm{~d})$, also known as the ACPA.

96. Belgian Code for Economic Law, art XII.22; French Postal and Electronic Communications Code, art L45.2.

97. British Telecommunications Plc \& Ors v One in A Million Ltd \& Ors [1998] EWCA Civ 1272 (23 July 1998).

98. AFP Paris, 'Facebook to French Court: Nude Painting did not Prompt Account's Deletion', The Guardian (London, 1 February 2018) <https://www.theguardian.com/technology/2018/feb/ 01/facebook-nude-painting-gustave-courbet> accessed 22 July 2019.

99. Associate Press, 'Swiss Museum Laments Facebook Ban of Images of Naked Statues', Courthouse News Service (Pasadena, 4 February 2019) <https://www.courthousenews.com/ swiss-museum-laments-facebook-ban-of-images-of-naked-statues/> accessed 26 July 2019.

100. James Crisp, 'Belgian Museums Urge Facebook to Allow Artistic Nudes in Advertising after Rubens Falls Foul of Censors', The Telegraph (London, 23 July 2018) <https://www.tele graph.co.uk/news/2018/07/23/flemish-museums-urge-facebook-allow-artistic-nudes-advertis ing/> accessed 22 July 2019. 
merely covered with a warning. ${ }^{101}$ Second, Uber has sanctioned drivers who repeatedly refuse rides by deactivating them for short periods of time. ${ }^{102}$ It has also excluded users for inappropriate ratings. At the micro level this means users endure an accumulated number of small 'reputational sanctions' by a community (not by platform operators themselves) which end up in a final sanction of exclusion by platform operators (at the macro level). These reputational sanctions can, however, be the result of a collection of discrimination biases, ${ }^{103}$ leading to questions about how these sanctions can be monitored/reviewed/kept under control (eg checking if they are based on accurate facts or acceptable reasons, etc.).

According to Belli and Venturini, sanctions should be subject to due process requirements. However, they are often imposed without notice or possible appeal and limits are imposed on the right to freedom of expression. ${ }^{104}$ Publicity and transparency can also be important factors in assessing the legitimacy of sanctions. Here ICANN can be mentioned. Despite its private nature, and its private system of dispute resolution, most decisions under the Uniform Domain-name Dispute-Resolution Mechanism (UDRP) are made accessible to the wider public - which can ensure more consistency and transparency against discrimination. ${ }^{105}$ Incrementally, some yardsticks seem to become acceptable for assessing the legitimacy of sanctions imposed by platform operators when sanctions originated at their very discretion. Would it be possible to identify overarching principles applicable to sanctions imposed in the digital space?

\subsection{Procedural legitimacy}

The processes followed to impose sanctions contribute strongly to assessing the legitimacy of their outcomes. Under the European Convention of Human Rights (ECHR), basic principles connected to a fair trial have been deemed to apply to non-State actors, such as disciplinary bodies of self-regulated professions. For instance, in the Le Compte case, ${ }^{106}$ the professional body regulating the medical profession in Belgium imposed sanctions against some of its members (suspending them). The suspended doctors appealed against the decision, first to the professional body itself and then

101. Facebook Community Standards, '12. Violence and Graphic Content' <https://www.face book.com/communitystandards/graphic_violence> accessed 22 July 2019; see also Facebook Community Standards, '13. Violence and Graphic Content' <https://perma.cc/KZ39-CZUA> accessed 22 July 2019.

102. Jeremias Prassl, Humans as a Service: The Promise and Perils of Work in the Gig Economy (OUP, Oxford 2018) 56 and footnote 22.

103. Ibid 62.

104. Jamila Venturini, Luiza Louzada, Marilia Maciel et al, Terms of Service and Human Rights: An Analysis of Online Platform Contracts (Editora Revan, Rio de Janeiro 2016) 29-39, 53-59, 65, 84 and 96-103.

105. See however M Scott Donahey, 'Divergence in the UDRP and the Need for Appellate Review' (2002) 5 Journal of Internet Law 1.

106. Le Compte, Van Leuven and De Meyere v Belgium App no 6878/75, 7328/75 (ECtHR 23 June 1981), extending the reach of art 6 ECHR to disciplinary actions undertaken by professional organisations (Frédéric Sudre (ed), Les Grands Arrêts de la Cour Européenne des Droits de l'Homme (8th edn, PUF, Paris 2017) 245-252); Albert and Le Compte v Belgium App no 7299/75, 7496/76 (ECtHR 10 February 1983 Grand Chamber). This remains a landmark case in this field (see eg Arman Zrvandyan, Casebook on European Fair Trial Standards in Administrative Justice (Council of Europe - Folke Bernadotte Academy 2016) 28). 
to the Belgian Court of Cassation. ${ }^{107}$ They then went to Strasbourg, complaining that Article 6 ECHR had not been complied with. The Strasbourg court decided that these types of disputes pertained to civil rights, so the guarantees resulting from Article 6 should be complied with (especially publicity). Platforms behave as modern selfregulating bodies and their decisions impact the civil rights and patrimonial and extra-patrimonial positions (eg advantages) of users. It thus seems that similar guarantees to the ones offered by Article 6 should also be offered when sanctions result from digital transactions and offending - at least when these transactions fall within the jurisdictions of Council of Europe Member States.

In practice, there is little systematic research available pertaining to the actual processes followed by platforms in imposing sanctions and offering procedural guarantees to users. However, anecdotal evidence shows that concern for them does exist. For instance, dispute resolution on Alibaba is based on a jury system or a human customer service representative. Yet $99 \%$ of disputes are resolved by negotiation, and hence without any human intervention. This is due partly to the fact that reducing human intervention on the platform is seen as a way to limit the reputational risks of bias. Jury members (who are volunteers) receive a reputation increase on the platform. This leads to a so-called 'scored society'. ${ }^{108}$ Similarly, Uber drivers who are excluded because of their low ratings ${ }^{109}$ can lodge an appeal to an internal ${ }^{110}$ or external ${ }^{111}$ body of peers, which reviews the exclusion. Similarly, YouTube content ID claims follow a procedure which resolves disputes over the attribution of content. A copyright holder requires that the content uploaded becomes attributed to her/him. Such a procedure does not necessarily lead to the removal of the content but sometimes merely leads to attribution of revenue to the copyright holder. ${ }^{112}$ It can be subject to a dispute and an appeal process. ${ }^{113}$ YouTube's copyright strikes, potentially leading to account removal, can also be challenged. ${ }^{114}$

\section{TOWARDS ALTERNATIVES BEYOND THE PUBLIC-PRIVATE DIVIDE?}

Sanctions on digital platforms call for the attention of international law. They can make issues arise when it comes to possible conflicts in States' use of their sovereign powers outside their jurisdictions. Platform operators may also have to organise specific procedures and/or entities when they impose sanctions to police behaviours. This may fall under the umbrella of global administrative law, for instance. Other issues arising from conflicts of law between actors, users and platforms connected to different

107. Highest court of the judicial order.

108. Katsh and Rabinovich-Einy (n 38) 65-66.

109. O'Connor v Uber Technologies, Inc., 82 F. Supp.3d 1133, 1151 (N.D. Cal. 2015).

110. Travis, 'Growing and Growing Up', Uber Newsroom (21 April 2016) <https://www.uber. com/newsroom/growing-and-growing-up/> accessed 22 July 2019.

111. Independent Drivers Guild, 'Deactivation Appeals Panel' < https://drivingguild.org/uberdeactivated/> accessed 22 July 2019.

112. Aide YouTube, 'Qu'est-ce Qu'une Revendication Content ID ?' <https://support.google. com/youtube/answer/6013276> (FR) accessed 22 July 2019.

113. Aide YouTube, 'Contester une revendication Content ID'<https://support.google.com/ youtube/answer/2797454> (FR) accessed 22 July 2019.

114. Aide YouTube, 'Principes de Base des Avertissements pour Atteinte aux Droits d'Auteur' <https://support.google.com/youtube/answer/2814000> (FR) accessed 22 July 2019. 
legal systems require solutions addressed by private international law. ${ }^{115}$ From these different factual circumstances, normative pluralism may ensue. This may also lead to a patchwork of possible sources of legal solutions, lacking clarity and coherence, transparency and accessibility. This can be a source of confusion for all actors involved in the digital space. Hence, alternatives to the traditional frameworks for regulating sanctions have to be considered.

One possible solution would be to include stakeholders and professionals in the definition of rules, enforcement and litigation pertaining to sanctions imposed in the digital space. These stakeholders and professionals form the backbones of epistemic communities and expertise in online rule-making and sanctions. Such involvement of epistemic communities in transnational governance has been discussed elsewhere. ${ }^{116}$ Paying special attention to all actors, including less powerful ones, should be considered. Platform operators cannot be trusted to guarantee such extensive inclusion. An external agency could be entrusted with oversight, if not regulatory, powers. ${ }^{117}$ Although the specific layout of this external agency would deserve more extended analysis, this paper would argue in a preliminary way that a hybrid form would be appropriate on the basis of current available experiences which could be built on.

Examples of these available experiences can be found in relation to the inclusion of stakeholders in participatory governance arrangements. Consumer collective bargaining agreements are a first instance of such participation. They have been developed in France, the UK and the Netherlands to promote fair contractual terms when consumers are involved. They are agreed upon sector-by-sector by an equal number of representatives of enterprises and consumer associations. They are binding for the given sector. ${ }^{118}$ A second instance of (limited) participatory governance arrangements is found in standard terms, ${ }^{119}$ which increase the transparency and thus the awareness of users. ${ }^{120}$ A third instance pertains to the political movement of 'platform cooperativism', which suggests that users, both consumers and content-providers, should become shareholders of platforms and operate them. They would benefit from revenues but also from voting power in a general assembly that would govern a platform. ${ }^{121}$

115. For a discussion about authority in this context, if not about sanctions, see Horatia Muir Watt, 'Theorizing Transnational Authority: A Private International Law Perspective' in Roger Cotterrell and Maksymilian del Mar (eds), Authority in Transnational Legal Theory: Theorising Across Disciplines (Edward Elgar Publishing, Cheltenham 2016) 325.

116. Sigrid Quack, 'Expertise and Authority in Transnational Governance' in Roger Cotterrell and Maksymilian del Mar (eds), Authority in Transnational Legal Theory: Theorising Across Disciplines (Edward Elgar Publishing, Cheltenham 2016) 361.

117. Rory Van Loo, 'The Corporation as Courthouse' (2016) 33 Yale Journal on Regulation 548, 584-591.

118. Jong-Youn Rha and Richard Widdows, 'The Internet and the Consumer: Countervailing Power Revisited' (2002) 20 Prometheus 107; Paul Nihoul, 'Projet de loi Relative aux Accords Collectifs de la Consommation, Présenté par le Ministre de la Protection de la Consommation et le Ministre de l'Economie' (2003) 1 Droit de la Consommation Consumentenrecht 89.

119. Bygrave (n 78) 145-147.

120. Momberg (n 31) 198-204.

121. Trebor Scholz, Platform Cooperativism: Challenging the Corporate Sharing Economy (Rosa Luxemburg Stiftung, New York 2016); Trebor Scholz and Nathan Schneider, Ours to Hack and to Own: The Rise of Platform Cooperativism, A New Vision for the Future of Work and a Fairer Internet (OR Books, New York 2016). 
Examples of these available experiences building on hybrid public-private solutions pertain also to decision-making and sanctioning. For instance, as this research has shown, reviews of sanctions by peers, with disciplinary council protection, could promote participation and inclusion in digital platforms. Additionally, reputation and feedback-based systems allow for forming an aggregate sanction, as users with low ratings lose opportunities for transactions. Last but not least, as in the UDRP, all decisions made by private actors should be made public, so as to support consistency and participation in decision-making. This would also support users' knowledge of appropriate expectations about a platform. Decisions and appeal processes should not be treated as trade secrets, as things currently stand. ${ }^{122}$

\section{CHALLENGES AHEAD FOR FUTURE SANCTIONS ON PLATFORMS}

Against a background of extensive literature examining how digital platforms are regulated through 'soft' mechanisms, this paper has argued that 'hard law' techniques, such as sanctions, are also very much used on digital platforms to police undesirable behaviours. It illustrated the use of these sanctions, suggesting that it is possible to find three different categories of sanctions: sanctions that find their source in hard (international and domestic) law, sanctions that find their sources in digital platforms' own normative production, and sanctions used in the course of litigation. Platform operators can have a very intense power of norm-setting and sanctions, with a tendency to concentrate power within themselves or unclear arrangements for dividing it across different entities. Yet this only applies to a small slice of users' lives: users retain their freedom in other respects. Regulatory competition between platforms may also allow for some checks and balances and self-limitation in the ways in which platforms set norms and enforce them. Things become trickier when platforms develop into entities able to reach broader slices of their users' lives, as has been the case for Uber in relation to the professional livelihood it provides to its drivers. In this case, platforms can develop behaviours deeply affecting individual freedoms.

This has led this paper to suggest that the ways in which the power to set, decide and enforce sanctions in the digital space transform the public-private divide, ie the allocation of roles between sovereign public bodies and free private actors is reshaped to become 'hybrid' when it comes to enforcing rules and monitoring compliance through a wide range of sanctions on digital platforms. Once the use and the diversity of these sanctions is plainly accepted it is then possible to start analysing the legal issues arising from these sanctions on digital platforms. This paper has sought to frame these issues under the overarching concept of their 'legitimacy' or the legal conditions under which sanctions are imposed. Legitimacy questions may arise in the ways in which norms setting sanctions are adopted, in the sanctioning of specific behaviour or in the procedures digital platforms follow when they impose sanctions.

Three main issues can be identified in this analysis for further discussion. The first one pertains to the discretion that platforms enjoy in sanctioning behaviour, discretion which is very minimally constrained by either procedures or substantive principles, as self-regulation mainly applies. The second one pertains to the possible ways in which this discretion may be structured and subject to some form of control. Current scholarship discusses, in this respect, how the proportionality principle may be relied on. ${ }^{123}$

122. Van Loo (n 117) 601.

123. Mart Susi, 'The Internet Balancing Formula' (2019) 25 European Law Journal 198. 
The third issue pertains to the vacuum in finding a source of legitimacy for the power that digital platforms exercise over individual freedoms. This paper has suggested that the public-private divide may have to be bridged in order to locate a possible source of legitimacy. As digital platforms indeed embody mixed forms of public and economic powers, ${ }^{124}$ it may be that new forms of legitimacy may develop based on publicprivate interactions. This is possibly a political choice that needs to be agreed upon by all actors, from the more powerful to the less powerful ones, from the more State-like to the more private-like ones, including businesses operating mainly in the physical world as they are also interested in what happens in the digital space.

For these reasons, the transnational nature of digital platforms calls for international public-private cooperation to address the hybridity of power in enforcement regimes: leading either to extending public-private participation in setting sanctions in the digital space or to setting up hybrid institutions to address the excesses to which sovereign platforms may be exposed. A future framework for assessing how platform operators set norms and ensure compliance through sanctions may need to start from individual users to see how best to protect their freedom when checks and balances around platforms' powers and sanctions are developed. The transnational public-private hybrids that platforms are becoming should not conceal who should be truly at the core of law's concern: third (public and private) parties affected by sanctions imposed in the digital space, and vulnerable parties, very much rooted in the physical world and possibly tricked into giving away their freedom under the cover of 'digital selffulfilment'. These are the ones who may suffer the economic, social and reputational consequences of sanctions in both the digital and physical worlds.

124. Enguerrand Marique and Yseult Marique, 'Beyond the Public and Private Divide on Digital Platforms? Revisiting Power Relationships' in Elisabetta Bani, Edyta RutkowskaTomaszewska and Beata Pachuca-Smulska (eds), Public Law and the Challenges of New Technologies and Digital Markets (CH Beck, Warsaw 2019, forthcoming). 